\title{
Modeling the Effects of Temperature on Oil Base Mud Viscosity Using Polynomial equation
}

\author{
${ }^{1}$ Igwilo K.C., ${ }^{2}$ Ikoro Godspower, ${ }^{3}$ Okoli Nnanna, ${ }^{4}$ Osueke G.O. ${ }^{5}$ Odo Jude, ${ }^{6}$ Anawe P.A.L. \\ ${ }^{1,2,3,4,5,}$ Federal University of Owerri, Nigeria. \\ ${ }^{6}$ Covenant University, Ota, Nigeria.
}

\begin{abstract}
This technical paper modeled and evaluates the effects of temperature on Oil Base Mud viscosity using Polynomial Equation. The Oil Base Mud was formulated and the laboratory measurements on rheology were carried out as per API standard. The plastic viscosity and yield point were modeled using Least square and Gaussian elimination methods. The proposed plastic viscosity and yield point models were also validated using linear plots and excel spreed sheat. The results of regression coefficients of $99.70 \%$ and $99.71 \%$ were obtained from modeled plastic viscosity and yield point polynomial equations respectively. $99.11 \%$ and $99.01 \%$ were got from plastic viscosity and yield point from validated linear plots, while $99.17 \%$ and $99.11 \%$ regression coefficients were obtained from excel spreed sheet model adequacy of plastic viscosity and yield point. Although, the results were close but the proposed models gave the best results when compared with the linear plots and excel spreed sheet results.
\end{abstract}

Keywords: Temperature, Yield Point, Plastic Viscosity, Polynomial Equation, Regression Coefficient, Excel spreed sheets, Linear plots, Proposed models.

\section{INTRODUCTION}

Drilling fluids in high temperature environment is challenging and dangerous as such, it calls for best techniques and profession to manage and reduce risk, minimize down time, increase personnel safety, reduce drilling cost, minimize formation damage, corrosion, lost circulation, stuck pipe, pressure losses, increase efficiency and safety. The temperature of the earth normally increases with depth and such the heat emanating from the earth is transmitted to the surface. Due to temperature and pressure effect, the rheology, visco- elastic and physical properties of the drilling fluids changes and as result affect the performance of drilling fluids. As formations are burned deep into the earth, their temperature will also increase. If the formations are totally sealed preventing escape of fluid then abnormal pressure will occur. The unstable flow of heat induced to the earth's core causes the subsurface temperature to increase with depth. Drilling mud, either oil or water base is most popular in the drilling program owing to their important functions required for a successful drilling operation. The failure of the drilling fluid as a result of factors such as elevated temperatures and pressures that limit tool, down hole equipment selection, down hole pressure determination, lost circulation, low penetration rates, acid gases, and compliance with safety and environmental regulations and in most cases contaminants can adversely impair its performance down hole and results in problems. The above factors are responsible for non-deliverability of the drilling fluids are known to have disrupted the flow properties and hence require a proper balance of mud properties under such high temperature conditions. Formulating a drilling fluid system that can adequately withstand drilling in high temperature environment is very challenging, but very often little attention is given to proper fluids design. Generally drilling into deeper formation requires drilling fluids that can withstand higher temperatures and pressures. The combined pressure and temperature effect on drilling fluid's rheology is complex. This provides a wide range of difficult challenges and mechanical issues that have negative impact on rheological properties when exposed to high temperature condition and contaminated with other minerals, which are common in deep drilling. Generally, properly designed drilling muds should be able to perform some of the major functions that are aimed at efficient, economical and safe operation of the drilling program. Therefore, efficient monitoring and well formulation is important for a safe drilling program as the depth increases. Carrying out laboratory measurements will help to predict and simulate more accurately the down hole conditions of the flow 
properties of the mud such as: gel strength (GS), yield point (YP), and plastic viscosity. It is pertinent to note that the effect of temperature and their associated control in drilling operation depends on the depth encountered during drilling operation and the chemical composition along with the rock cuttings can be collectively be considered as a challenge during operation.

Vasan and Gatlin (1958) of the University of Tuisa, Oklahoma, conducted experiment on effect of temperature on the flow properties of oil mud, and investigated that plastic viscosity and apparent viscosity decrease with temperature increase. Sinha (1961) conducted related studies on the determination of the equivalent viscosity of drilling fluids under high temperature and pressure, and revealed that both temperature and pressure fervently affect the equivalent viscosity of oil based mud. Annis (1967) reported that flow properties of water base mud samples were measure at temperature up to $300^{\circ} \mathrm{F}$.Plastic viscosity decreased with increase in temperature at reasonably same rate as the viscosity of water up to $225^{\circ} \mathrm{F}$; it then began to increase slowly, remaining almost constant till $300^{\circ} \mathrm{F}$.

The effect on invert emulsion fluids is more significant than on water-based fluids, Barlett, L.E(1967) studied the effect of temperature and discovered significant decrease in viscosity(by half) of a particular ligno-sulfonate mud when its temperature was increased from $80^{\circ} \mathrm{F}$ to $140^{\circ} \mathrm{F}$. Drilling fluid viscous behaviour is a critical issue in the success of drilling operations, particularly for drill cuttings removal. The properties that drilling fluids should possess are appropriate viscosity, highshear thinning behaviour and a finite yield stress for suspending and transferring drill cuttings to the surface (Kelessidis et al., 2007). Nevertheless, the rheological characterization of these systems is not a trivial task because of the inherent heterogeneous nature of the system. The use of non-conventional geometries, such as helical ribbons and blade turbines, has become valuable tools for characterizing the viscous flow behaviour of disperse systems, mainly due to the elimination of serious wall slip effects of apparent yield stress materials (Barnes and Nguyen,2001; OShea and Tallon, 2011). As expected, drilling fluid plastic viscosity always decreases with temperature (Joshi and Pegg, 2007), being its dependence very similar to that of the base oil. These results suggest that the viscous flow behaviour of these fluids is largely governed by the viscosity of the base oil, as has been reported elsewhere (Herzhaft et al., 2001). The plastic viscosity depends on the viscosity of the liquid phase and the concentration and size of solids present. The solids present in the mud can be considered either active or inactive. Increasing the concentration by volume of solids in the mud can increase plastic viscosity of the mud. If the volume percent of solids remains constant, then reducing the size of the solids would also increase the plastic viscosity due to the increased surface area exposed. Plastic viscosity is also a function of the viscosity of the fluid phase. As the viscosity of the fluid phase decreases with increased temperature, the plastic viscosity will decrease proportionally (Smith, 1974).

\section{MeThodology}

The methology of this technical paper was done in two phases:

Laboratory measurements and development of Mathematical model using laboratory measured data.

Oil base mud was formulated with mud additives and their rheology measurements were carried out as per API standard as shown in table 1 below, under laboratory conditions ambient temperature $80^{\circ} \mathrm{F}$, to determine its effectiveness before being exposed to temperatures of $100^{\circ} \mathrm{F}, 120 \mathrm{~F}, 150^{\circ} \mathrm{F}$, and $180^{\circ} \mathrm{F}$.

Table1: Oil Base Mud Formulations

\begin{tabular}{|l|l|l|l|l|}
\hline Drilling Chemicals & Functions & Sp. Gr & Measurement & $\begin{array}{l}\text { Timing } \\
\text { Hamilton mixer }\end{array}$ \\
\hline $\begin{array}{l}\text { Base oil (Mineral oil mud } \\
\text { System, 139ppb) }\end{array}$ & Mineral oil invert mud system & 0.77 & $180 \mathrm{ml}$ & 1 \\
\hline $\begin{array}{l}\text { Organophilic clay } \\
\text { (5ppb) }\end{array}$ & Viscosifier and gelling agent & 2.60 & $5.00 \mathrm{~g}$ & 30 \\
\hline Lime $\left(\mathbf{C a}(\mathbf{O H})_{\mathbf{2}}\right) \mathbf{( 5 p p b )}$ & $\begin{array}{l}\text { Alkalinity control and neutralization of } \\
\text { acidic gases }\left(\mathrm{H}_{2} \mathrm{~S}\right) /\left(\mathrm{CO}_{2}\right)\end{array}$ & 2.30 & $5.00 \mathrm{~g}$ & 5 \\
\hline Gilsonite(4ppb) & $\begin{array}{l}\text { Fluid loss control for high } \\
\text { temperature conditions. }\end{array}$ & 1.77 & $4.00 \mathrm{~g}$ & 3 \\
\hline Cacl $\mathbf{2}(\mathbf{1 6 p p b})$ & Water phase salinity balance. & 3.48 & $16.0 \mathrm{~g}$ & 2 \\
\hline Water(123.97ppb) & Internal phase & 1.00 & $124 \mathrm{ml}$ & 3 \\
\hline $\begin{array}{l}\text { Primary Emulsifier } \\
\text { (9ppb) }\end{array}$ & $\begin{array}{l}\text { Provides emulsion stability ,wetting } \\
\text {,filtration control and temperature stability }\end{array}$ & 0.93 & $9.68 \mathrm{ml}$ & 3 \\
\hline
\end{tabular}


Modeling the Effects of Temperature on Oil Base Mud Viscosity Using Polynomial equation

\begin{tabular}{|l|l|l|l|l|}
\hline $\begin{array}{l}\text { Secondary Emulsifier } \\
\text { (5ppb) }\end{array}$ & $\begin{array}{l}\text { Provides emulsion stability, wetting, } \\
\text { filtration control and temperature stability }\end{array}$ & 0.92 & $5 . .43 \mathrm{ml}$ & 2 \\
\hline Barite (73.5ppb) & Weighting agent & 4.20 & $\begin{array}{l}\text { It depends on } \\
\text { ther required } \\
\text { mud weight }\end{array}$ & 15 \\
\hline
\end{tabular}

\section{Modeling of the Plastic Viscosity, Yield Point at given Temperatures}

The rheological values or data obtained from the experimental test have been analzed to generate correlations equation between plastic viscosity, and yield point of the drilling fluid over temperatures of $80^{\circ} \mathrm{F}, 100^{\circ} \mathrm{F}, 120^{\circ} \mathrm{F}, 150^{\circ} \mathrm{F}$ and $180^{\circ} \mathrm{F}$. The following procedures were followed:

(1) Apply the polynomial equation of the form:

$\mathrm{T}=\mathrm{a}_{0}+\mathrm{a}_{1} \mathrm{x}+\mathrm{a}_{2} \mathrm{x}^{2}$ for plastic viscosity $\mathrm{T}$, at temperature $\mathrm{x}$.

Where $\mathrm{a}_{0}, \mathrm{a}_{1}$ and $\mathrm{a}_{2}$ are obtain from table 2 in the appendix.

(2) Normalised the equations using Least Square methods to obtain table3

(3) From table 3, obtain 3 equations, form 3 x 3 matrix and solved them using Gaussian Elimination method.

(4) The equation $T=0.0005 \mathrm{x}^{2}-0.617 \mathrm{x}+131.06$ was obtained.

(5) Also, yield point equation, $\mathrm{YP}=0.0001 \mathrm{x}^{2}-0.1521 \mathrm{x}+28.303$ was obtained using table 4 through steps 1,2 and 3 as stated above.

They were then validated with the linear plots as shown in figures 1,2 and in excel spreed sheet model adequacy tables 5 and 6 in the appendix.

\section{Assumptions made}

(1) Minimum or increase in mud weight

(2) Minimum or no entrance of formation solids into the active system

(3) Maintain optimum screen selection

(4) Monitor and change any worn out screen when making connections.

\section{RESUlts Discussion ANd MODEL VALIDATION}

The effects of temperature on plastic viscosity and yield point were determined graphically using the results shown in table 2 at given temperatures.

Table 2: Oil Base Mud Properties obtained from Laboratory Measurements at given Temperatures.

\begin{tabular}{|l|l|l|l|l|l|}
\hline Temperature $\left({ }^{0} \mathrm{~F}\right)$ & 80 & 100 & 120 & 150 & 180 \\
\hline Plastic Viscosity $(\mathrm{cp})$ & 84 & 75 & 66 & 47 & 37 \\
\hline Yield Point $\left(\mathrm{lb} / 100 \mathrm{ft}^{2}\right)$ & 17 & 14 & 11 & 9 & 4 \\
\hline Mud weight $(\mathrm{ppg})$ & 10.2 & 10.2 & 10.2 & 10.2 & 10.2 \\
\hline
\end{tabular}

Figures 1 and 2 are the plots made from table 2, that is, the experimental measurements while figures 3 and 4 are the plots obtained from the plastic viscosity and yield point equations of the form $\mathrm{T}=0.0005 \mathrm{x}^{2}-0.617 \mathrm{x}+131.06$ and $\mathrm{YP}=0.0001 \mathrm{x}^{2}-0.1521 \mathrm{x}+28.303$ respectively . Generally, the results showed that the fluid system is sensitive to temperatures. As the temperature increases from $80^{\circ} \mathrm{F}$ to $180^{\circ} \mathrm{F}$, the yield point which is the carrying capacity of the mud is more affected than the plastic viscosity. Above $120^{\circ} \mathrm{F}$, which is the API standard test temperature for viscosity, there is more temperature effect as shown in figures 1 to 4 . It was also noticed that, at temperatures above $150^{\circ} \mathrm{F}$, charged particles experienced enough distance among themselves which results in the alteration in the balance between the interparticles attractive and repulsive forces and the degree of dispersion in the mud system. Also the qualitative plastic viscosity is inversely proportional to the Reynold number which is one of the major parameters for hole cleaning decreased. 


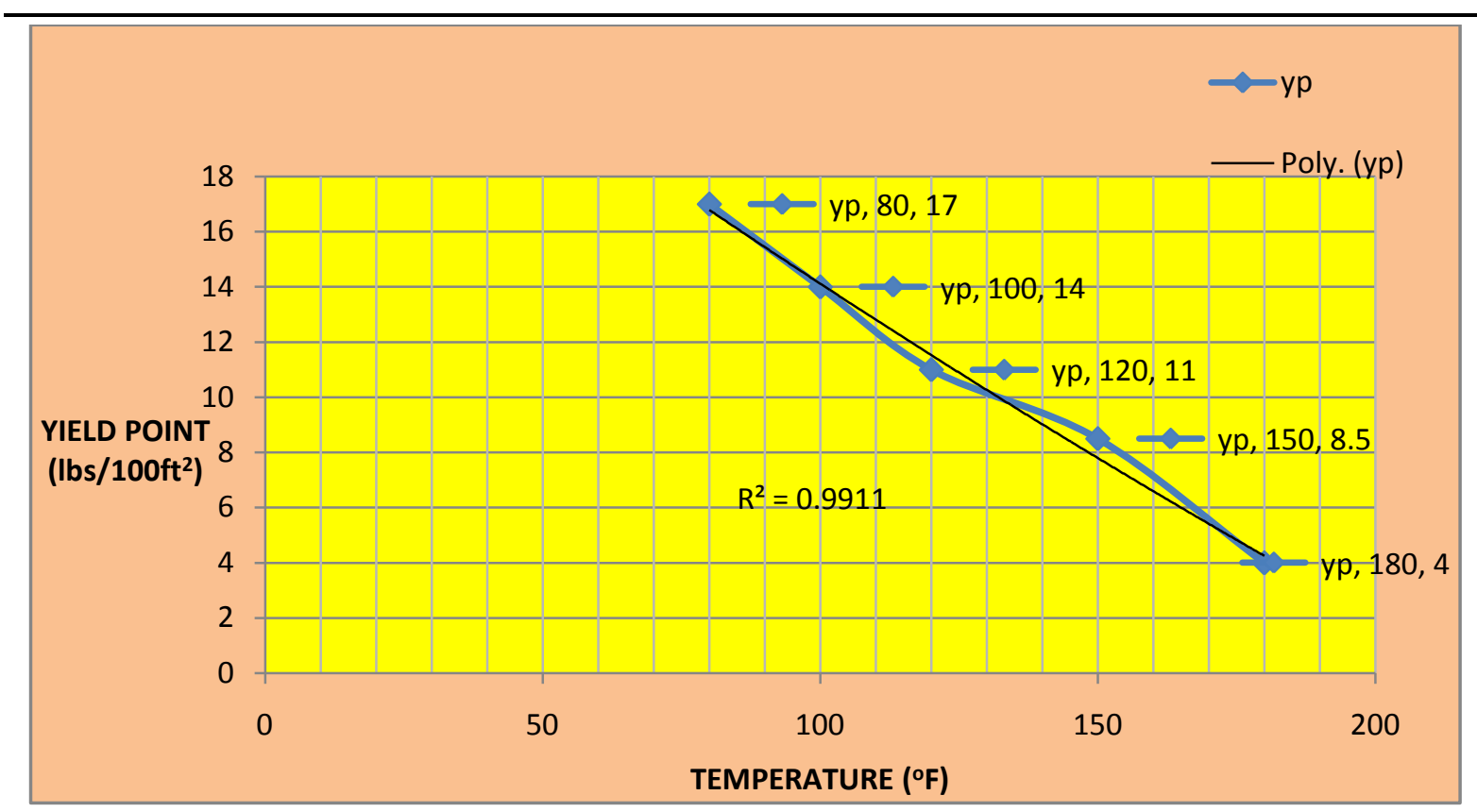

Figure1. Yield Point vs. at various Temperatures.

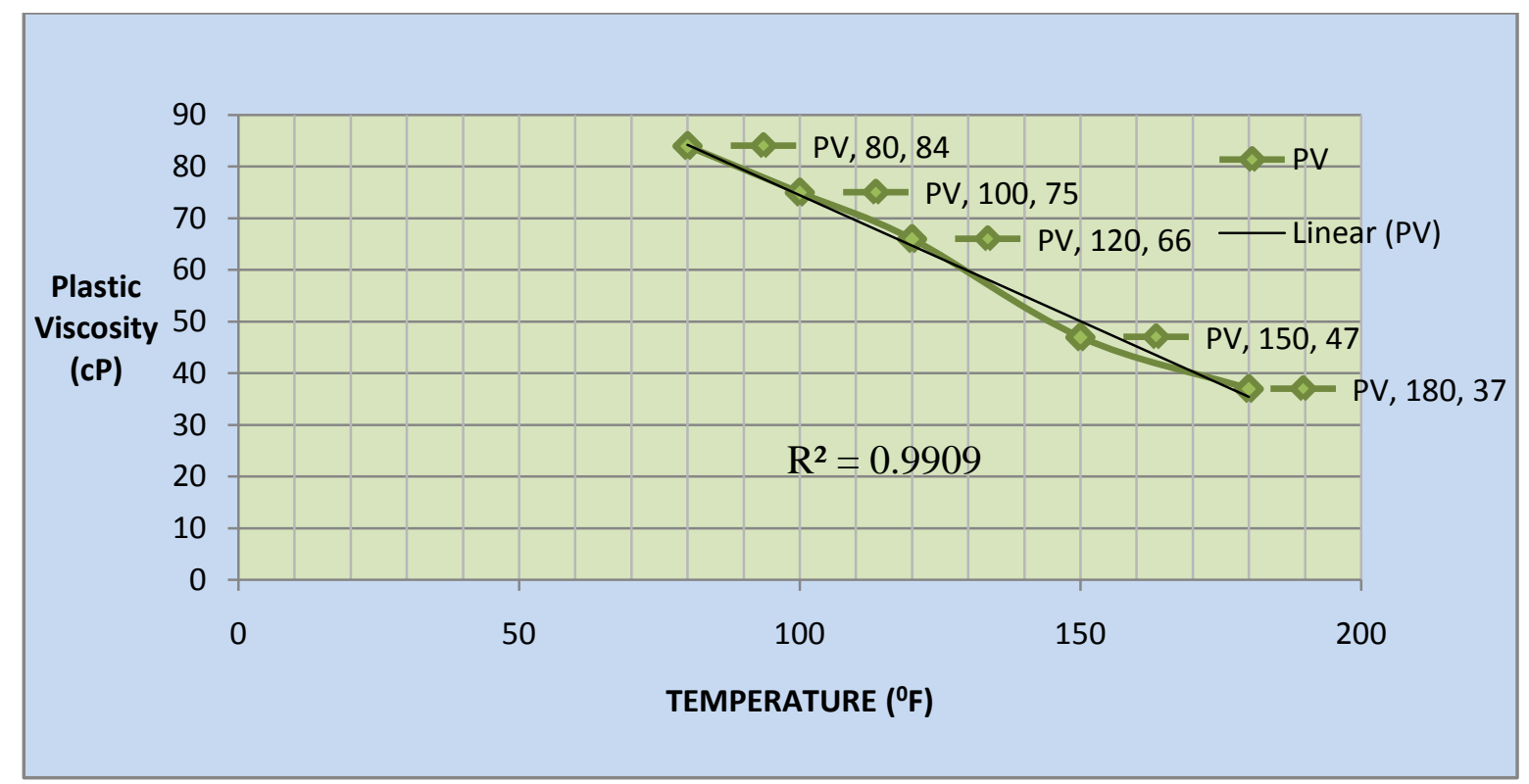

Figure2. Plastic Viscosity at various Temperatures

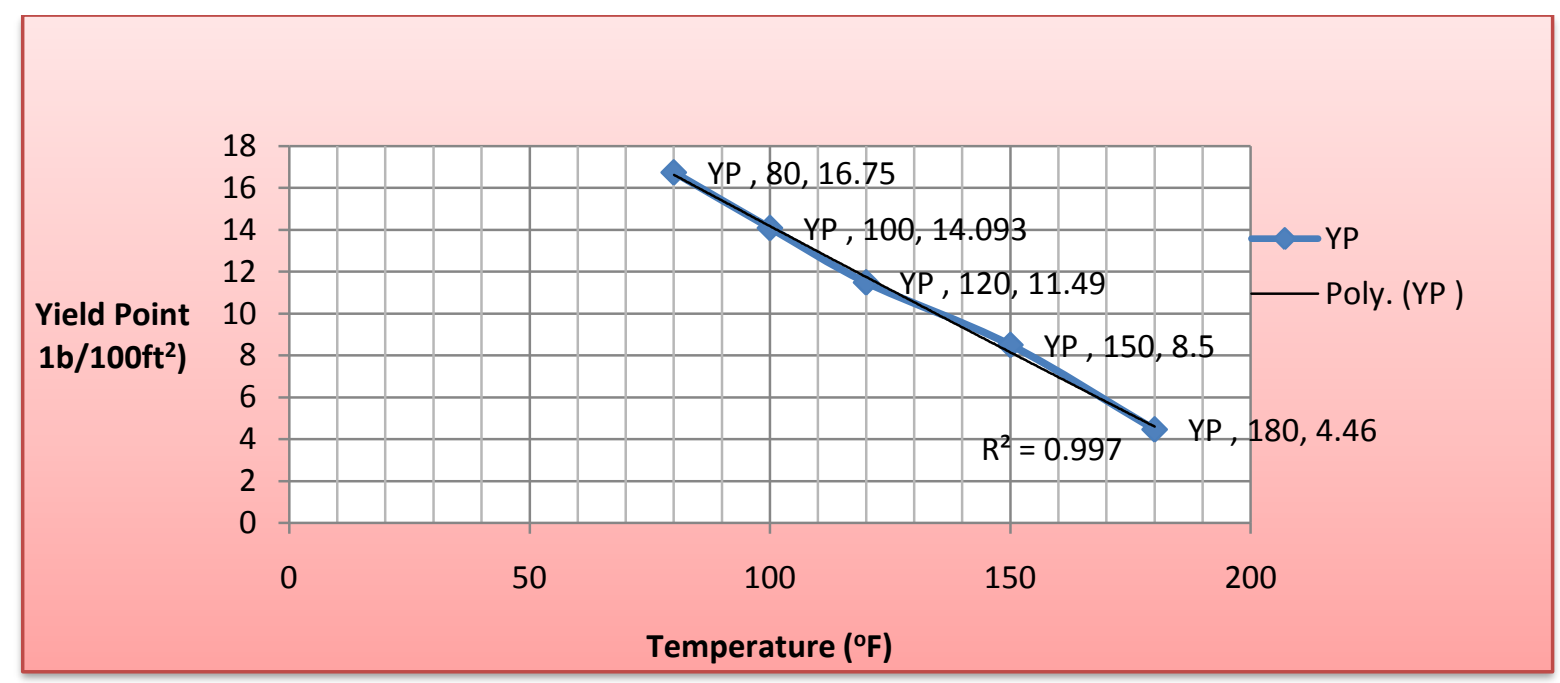

Figure3. Modeled Yield point at various Temperatures 


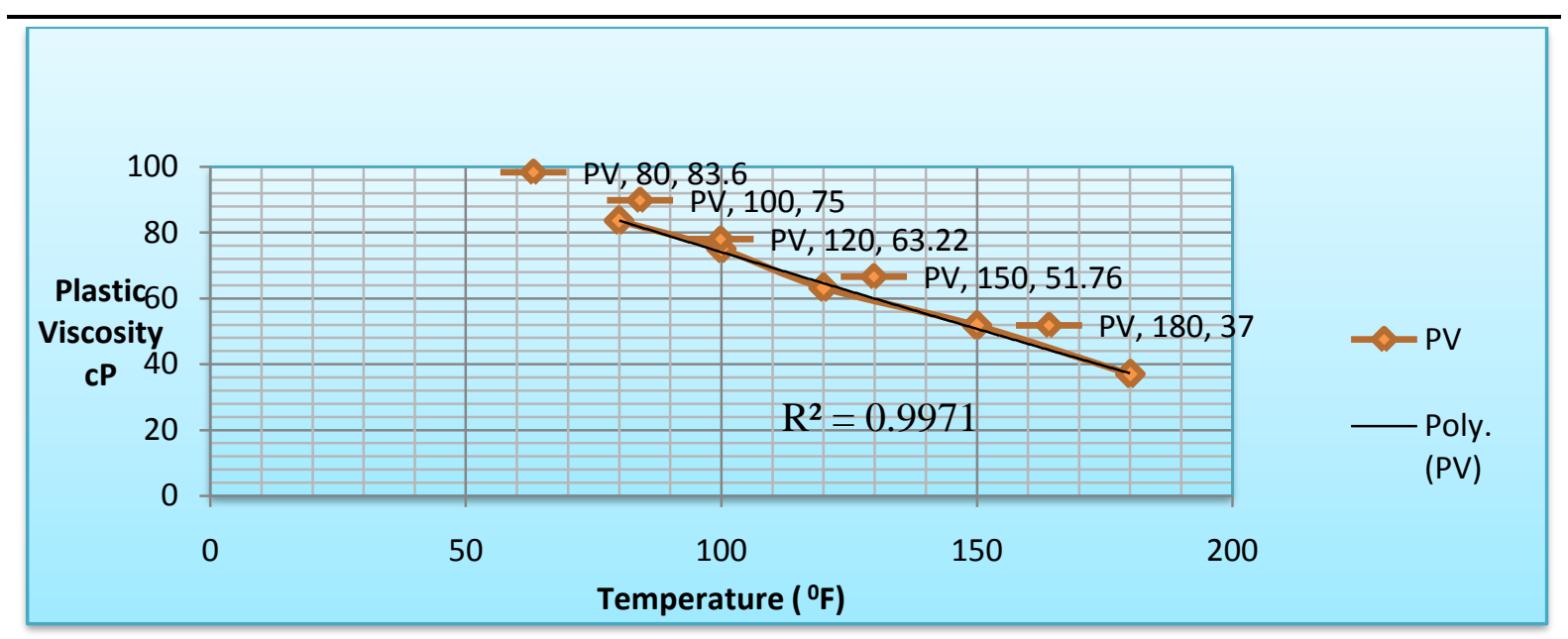

Figure4. Modeled Plastic Viscosity at various Temperatures

The coefficients of regression $\left(\mathrm{R}^{2}\right)$ from figures 1 and 2 are 0.9911 and 0.9901 . This shows a slight improvement of 0.9970 and 0.9971 from figures 3 and 4 of the modeled yield point and plastic viscosity respectively. This therefore, portrayed that the effects of temperature on both the yield point and the plastic viscosity is better defined in figures 3 and 4 than figures 1 and 2. Also, from figures 5 and 6 of excel spreed sheet of model adequacy, the coefficient of regression for both plastic viscosity and yield point are 0.9917 and 0.9911 respectively. Although, $\mathrm{R}^{2}$ in tables 5 and 6 are close but Polynomial equation still gave the best result. The $\mathrm{R}^{2}$ of the linear the equations in tables 5 and 6 are comparable to the ones plotted in figures 1 and 2 .

Table3. Normalised equation for Temperature and Plastic Viscosity

\begin{tabular}{|l|l|l|l|l|l|l|l|}
\hline $\mathrm{S} / \mathrm{N}$ & $\mathrm{T}\left({ }^{0} \mathrm{~F}\right)$ & $\mathrm{X}$ & $\mathrm{X}^{2}$ & $\mathrm{X}^{3}$ & $\mathrm{X}^{4}$ & $\mathrm{TX}$ & $\mathrm{T} \mathrm{X}^{2}$ \\
\hline $\mathrm{I}$ & 80 & 84 & 7056 & 592704 & 49787136 & 6720 & 564480 \\
\hline 2 & 100 & 75 & 5625 & 421875 & 31640625 & 7500 & 562500 \\
\hline 3 & 120 & 66 & 4356 & 287496 & 18974736 & 7920 & 522720 \\
\hline 4 & 150 & 47 & 2209 & 103823 & 48796881 & 7050 & 331350 \\
\hline 5 & 180 & 37 & 1309 & 50653 & 1874161 & 6660 & 246420 \\
\hline $\mathrm{N}=5$ & $£ \mathrm{~T}=630$ & $£ \mathrm{X}=309$ & f $^{2}=20615$ & $£ \mathrm{x}^{3}=1456551$ & $\mathrm{x}^{4}=107156339$ & $£ \mathrm{Tx}=35850$ & $£ \mathrm{Tx}^{2}=2222470$ \\
\hline
\end{tabular}

Table4. Normalised equation of Temperature and Yield Point

\begin{tabular}{|l|l|l|l|l|l|l|l|}
\hline $\mathrm{S} / \mathrm{N}$ & $\mathrm{T}\left({ }^{0} \mathrm{~F}\right)$ & $\mathrm{X}$ & $\mathrm{X}^{2}$ & $\mathrm{X}^{3}$ & $\mathrm{X}^{4}$ & $\mathrm{TX}$ & $\mathrm{T} \mathrm{X}^{2}$ \\
\hline $\mathrm{I}$ & 80 & 17 & 289 & 4913 & 83521 & 1360 & 23120 \\
\hline 2 & 100 & 14 & 196 & 2744 & 38416 & 1400 & 19600 \\
\hline 3 & 120 & 11 & 121 & 1331 & 14641 & 1320 & 14520 \\
\hline 4 & 150 & 8.5 & 72.25 & 614.125 & 5220.06 & 1275 & 10837.5 \\
\hline 5 & 180 & 4 & 16 & 64 & 256 & 720 & 2880 \\
\hline $\mathrm{N}=5$ & $£ \mathrm{~T}=630$ & $£ \mathrm{x}=54.5$ & $£ \mathrm{x}^{2}=694.25$ & $£ \mathrm{x}^{3}=9666.125$ & $£ \mathrm{x}^{4}=142054.06$ & $£ \mathrm{Tx}=6075$ & $£ \mathrm{Tx}^{2}=70957.5$ \\
\hline
\end{tabular}

Table 5: Excel Sheet Model Adequacy for Plastic Viscosity

\begin{tabular}{|l|l|l|l|}
\hline $\begin{array}{l}\text { Regression type (For Yield } \\
\text { Point) }\end{array}$ & Equations & $\mathrm{R}^{2}$ & $\mathrm{R}^{2}(\%)$ \\
\hline Power & $8572.3 \mathrm{x}^{-1.038}$ & 0.9543 & 95.43 \\
\hline Polynomial & $0.0005 \mathrm{x}^{2}-0.617 \mathrm{x}+131.06$ & 0.9917 & 99.17 \\
\hline Exponntial & $172.9 \mathrm{e}^{-0.009 \mathrm{x}}$ & 0.9869 & 98.69 \\
\hline Linear & $-0.488 \mathrm{x}+123.28$ & 0.9909 & 99.09 \\
\hline Logarithm & $-60.18 \ln (\mathrm{x})+350.42$ & 0.9814 & 98.14 \\
\hline
\end{tabular}

Table6. Excel Sheet Model Adequacy for Yield Point

\begin{tabular}{|l|l|l|l|}
\hline Regression type (For Yield Point) & Equations & $\mathrm{R}^{2}$ & $\mathrm{R}^{2}(\%)$ \\
\hline Power & $28082 \mathrm{x}^{-1.661}$ & 0.8955 & 89.55 \\
\hline Polynomial & $0.0001 \mathrm{x}^{2}-0.1521 \mathrm{x}+28.303$ & $\mathrm{R}^{2}=0.9911$ & 99.11 \\
\hline Exponntial & $55.477 \mathrm{e}^{-0.014 \mathrm{x}}$ & $\mathrm{R}^{2}=0.9475$ & 94.75 \\
\hline Linear & $-0.1253 \mathrm{x}+26.69$ & 0.9905 & 99.05 \\
\hline Logarithm & $-15.48 \ln (\mathrm{x})+85.156$ & $\mathrm{R}^{2}=0.9846$ & 98.46 \\
\hline
\end{tabular}




\section{Conclusion}

The following conclusions can be made from the analysis presented in this paper:

1) The results have shown that increase in temperature affects both physical and chemical properties of oil base mud.

2) The experimental results on the rheology of oil base mud and that of the model suggest a good match with the validated result which in turn deduce a polynomial equation between the plastic viscosity, yield point and temperatures.

3) The polynomial model shows a good match of coefficient of regression $\left(R^{2}\right)$ of 0.9970 and 0.9971 for both yield point and plastic viscosity respectively. This means that model represent a minium of $99.7 \%$ of the data which is desirable.

4) The polynomial model is therefore the best when describing the effect of temperatures on the plastic viscosity and the yield point than other models.

\section{CONTRIBUTION TO KNOWLEDGE}

The proposed Polynomial model that can predict rheological behavior of drilling fluid as well as the effects of the temperature on the oil base mud viscosity was developed.

\section{REFERENCES}

[1] Annis, M. R. (1967). High Temperature Flow Properties of Water-Based Drilling Fluids. J. Pet. Tech. (August 1967), pp.1074-1080.

[2] Bartlett, L.E.(1967). Effects of Temperature on the Flow Properties of Drilling Fluids. SPE Paper 1861 presented at the SPE Annual Meeting of AIME, Houston, Texas, 1-4 October.

[3] Herzhaft B.(2001). Rheological Properties of Drilling Muds in Deep Offshore Conditions, SPE/IADC Drilling Conference, Amsterdam, Netherlands, 27 Feb.-1 March.

[4] Joshi R.M., Pegg M.J. (2007). Flow properties of biodiesel fuel blends at low temperatures, Fuel $86,143-151$.

[5] Kelessidis V.C., (2007). Gelation of water-bentonite suspensions at high temperature and rheological control with lignite addition, Appl. ClaySci. 36, 221-230 Shea J.-P., Tallon C. (2011). Yield stress behavior of concentrated silica suspensions with temperature. Responsive polymers, Colloids Surf. A 385, 40-46

[6] Rheological Models. Schlumberger, http://www.glossary.oilfield.slb.com/. Downloaded 2 July 2007.

[7] Sinha, B. K. (1961). A New Technique to Determine the Equivalent Viscosity of Drilling Fluids under High Temperatures and Pressures. SPE 2384.

[8] Vasan, S. and Gatlin, C. (1958). The Effect of Temperature on the Flow Properties of ClayWater Drilling Muds. AIME Tech. Note, No.2025, pp.59 


\section{AUTHORS' BIOGRAPHY}

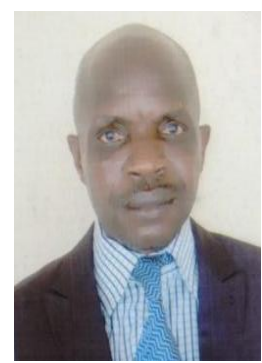

Dr Igwilo Kevin Chinwuba, holds a bachelor's degree in Petroleum Engineering, master's degree and doctorate degree also in Petroleum Engineering. He is an Assistant Professor, Federal University of Technology, Owerri, Nigeria; a Visiting Lecturer, African University of Science and Technology, Abuja, currently doing his Sabbatical Leave with Covenant University, Nigeria. Kevin has over 20years oilfield working experience as a Drilling Engineer, Drilling Fluids Engineer/Instructor, Mud Logger, Wellhead Engineer, Production Chemist and a Well Site Petroleum Engineer with Schlumberger, Baker Hughes, Shell, Interdrill and Vetco Gray. He has worked in different parts of the world :Nigeria, Ghana, Guinea, Qatar and UK. He authored/co-authored over 25 Journal Publications and 1 text book on drilling fluids. and review articles for publication in journals. He is the Managing Director of Ken Pam Mud School.

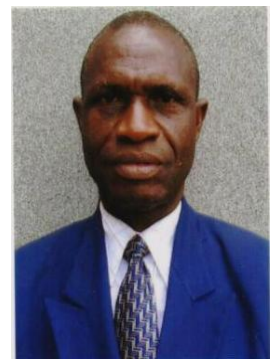

Dr Anawe Paul Lucky, is currently an Associate Professor and currently the Acting Head of Department, Petroleum Engineering at Covenant University, Nigeria. He holds a bachelor's degree in Chemical Engineering, master's degree also in Chemical Engineering, doctorate degree in Lubrication Engineering ( Azerbaidjan State Oil and Gas Academy, USSR ). Paul was the Liquefied Petroleum Gas Manager in 1991 with elf Petroleum, Chemical Division in Nigeria. He is a registered engineer in Nigeria ( R. Eng; COREN ). He has authored/co-authored over 42 journal publications and articles. His current research interest is on drilling fluids, various methods of crude oil treatment, Petroleum Refining/Petrochemical issues, Corrosion issues in the oil and gas industry.

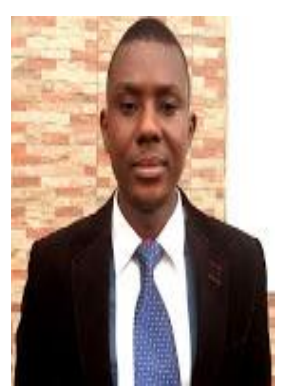

Okoli Nnanna Onwuegbueha, Well trained and seasoned Petroleum Engineer, Capable of working in a multi-discipline and multi-cultural environment, excellent knowledge in petroleum engineering studies. Great experience in petrophysical analysis and reserve evaluation, Familiar with cutting edge technology software used in the oil and gas industry and other in-house engineering software, excellent written and oral communication skill, good presentation skills, and excellent background in petroleum engineering research studies.

Current affiliation: Lecturer, Department of Petroleum Engineering, Federal University of Technology Owerri; Research fellow of Petroleum Economics, Management and Policy, Emerald Energy Institute, University of Port-Harcourt.

Former Affiliations: Graduate Engineer Intern, Mobil Producing Nigeria MPN, Exxon Mobil Corporation (2011-2013). Student Trainee, Transocean Support Services, Nigeria (2009)

Research Interests: Global oil and gas industry structure, conduct, and performance analysis; oil and gas exploration and production economics and policy research 